Doi: https://doi.org/10.31578/jebs.v6i2.240

\title{
Effect of Drama Technique on Achievement in English Reading Comprehension of Junior Secondary School Students
}

Oluseun F. Lawal*

\begin{abstract}
The study examined the effect of drama technique on achievement in English reading comprehension of junior secondary school students. This study adopted the pre-test - post-test quasi-experimental design. The population of the study comprised of all junior secondary school students in ljebu-North local government, Ogun state. Two junior secondary schools were randomly selected for the purpose of the study. The students in the two schools were randomly assigned to experimental and control groups. The instrument used for data collection was Reading Comprehension Achievement Test which has reliability coefficient of 0.72 . The experiment lasted for six weeks. The data were analysed by Analysis of Co-Variance (ANCOVA) at 0.05 level of significance. The results show a significant main effect of drama technique and gender on students' achievement in reading comprehension. The results further show a significant interaction effect of drama technique and gender on students' achievement in reading comprehension. The study recommends that teachers should adopt the use of drama technique in teaching comprehension.
\end{abstract}

Keywords: drama technique, reading comprehension, achievement in reading

\section{Introduction}

In recent years, English Language teachers have recognized the importance of the underlying dynamics of culture in second language communication. Language teaching involves dealing with four basic skills, namely: listening, speaking, reading and writing. These four basic skills are complementary to one another like a system where fault in one affects the other parts. Of these skills, reading is at the centre of every academic success and acquisition of general literacy. Reading comprehension is a process that consists of making predictions, interacting with the text, decoding the meaning embedded in the text (Tortello, 2004), providing the active construction of meaning (Jennings, Caldwell, \& Lerner, 2006), and building up schemata in reconstructing the text's meaning. Cunningham and Stanovich (1997) explain that reading has cognitive consequence that extends beyond its immediate task of lifting memory meaning from a particular passage and provides a very wide avenue for the readers to negotiate meaning as the readers in the light of experiences brought into the reading.

De Certeau (2008) views reading as a complex cognitive process of decoding symbols in order to construct or derive meaning (reading comprehension). Reading is a means of language acquisition, communication, and of sharing information and ideas. Like all languages, it is a complex interaction between the text and the reader which is shaped by the reader's prior

\footnotetext{
* Institute of Education, Olabisi Onabanjo University, Ago-Iwoye, Ogun State, Nigeria

Corresponding E-mail: lawal.oluseun@oouagoiwoye.edu.ng
} 
knowledge, experiences, attitude, and language community which is culturally and socially situated. Mabekoje (2003) opines that reading is essentially the comprehension of printed symbols.

The reading process requires continuous practice, development, and refinement. In addition, reading requires creativity and critical analysis. Consumers of literature make ventures with each piece, innately deviating from literal words to create images that make sense to them in the unfamiliar places the texts describe. Because reading is such a complex process, it cannot be controlled or restricted to one or two interpretations. There are no concrete 'laws' in reading, but it rather allows readers an escape to produce their own products introspectively. This promotes a deep exploration of texts during the interpretation.

Readers use a variety of reading strategies to assist with decoding (to translate symbols into sounds or visual representations of $\underline{\text { speech) }}$ and comprehension. Readers may use context clues to identify the meaning of unfamiliar words. Readers integrate the words they have read into their existing framework of knowledge or schema (schemata theory). The process of reading results from a negotiation of meaning between the text and its reader (Pritchard et al., 2012). Oladunjoye (2005) sees reading as an interactive process in which readers comprehend, interpret and respond to texts according to what they already know. Reading does not draw on one kind of cognitive skill, nor does it have a straightforward outcome, most texts are understood in different ways by different readers. Hence reading plays an important role in English language teaching at various levels.

The importance of the English language in Nigeria needs not be overemphasized, since it is the country's second language and official language and also the major subject on which the educational advancement and lucrative employment are based. Hence, reading which is an important component of learning the English language is learnt from pre-primary level of education up to the tertiary institution. There is a great deal of evidence that children's reading proficiency in their native language is a strong predictor of their ultimate English reading performance (Reese et al., 2000). Since English is an international language, it is necessary for students to develop the language skills required to study in English, and to evolve strategies to assist this development.

However, in spite of the numerous benefits of reading in the education and its multiplier effect on individuals and the society, reading is still not well taught in our schools (Etim, 2007; Ikota, 2004; Omojuwa, 1991; Maduabuchi, 2006). This has a negative implication on the students' reading comprehension passage in the classroom while teaching other subjects or for the purpose of examination. An alternative way of passing the message in comprehension passage is through drama.

Drama is a composition in verse or prose presenting a story in pantomime or dialogue, containing conflicts of characters, particularly the ones who perform in front of audience on the stage. Drama is one of the best literary forms through which dramatists can directly speak to their readers or audience as well as they can receive instant feedback of audience. Dramatists use their characters as a vehicle to convey their thoughts, values such as poets do with personas, and novelists do with narrators. Since drama uses spoken words and dialogues, thus language of characters plays a vital role, as it may give clues to their feelings, personalities, backgrounds, and change in feelings, etc. In drama the characters live out a story without any comments of the author, providing the audience a direct presentation of characters' life experiences (Kariuki \& Humphrey, 2010).

Drama has recently become a center of attention and an important part of the literature curriculum in many countries (Urian, 2000). Since it is a potentially powerful tool for instruction and learning (Schneider \& Jackson, 2000; Smith \& Herring, 1993). Drama activities are useful in the development of oral communication skills, and reading and writing as well. Drama activities help students to communicate in the foreign language including those with limited vocabulary (Aldavero, 2008). Drama as a learning tool is beneficial to all categories of students. One of the major advantages of drama is that it helps students to comprehend the world they live in and construct their knowledge and increases the chances for children to express themselves 
independently in any subject area, including reading. The link between drama and reading comprehension is a strong one (Kelner \& Flynn, 2006), drama helps students to develop skills embedded in the reading process, such as contextualizing what they read in a text to their own experience, feelings, attitudes, ideas, values and life situations (Booth, 1985).

The following are some types of drama:

Comedy - Comedies are lighter in tone than ordinary writers, and provide a happy conclusion. The intention of dramatists in comedies is to make their audience laugh. Hence, they use quaint circumstances, unusual characters and witty remarks.

Tragedy-Tragic dramas use darker themes such as disaster, pain and death. Protagonists often have a tragic flaw—a characteristic that leads them to their downfall.

Farce- Generally, a farce is a nonsensical genre of drama, which often overacts or engages slapstick humour.

Melodrama- Melodrama is an exaggerated drama, which is sensational and appeals directly to the senses of audience. Just like the farce, the characters are of single dimension and simple, or may be stereotyped.

Musical Drama - In musical drama, the dramatists not only tell their story through acting and dialogue, nevertheless through dance as well as music. Often the story may be comedic, though it may also involve serious subjects.

Using drama as method of teaching comprehension in schools in Nigeria is not very common, it is somewhat believed that it is time consuming compared to reading (Rose, Parks, Androes, \& McMahon, 2000), however contrary to such claims, Dupont (1989) states that drama is a more effective instructional strategy than traditional reading instruction for enhancing reading comprehension skills of students as they use reading comprehension strategies while acting. Tate (2005) opines that those who take part in a drama activity have true-to- life experiences by making use of strategies such as decision-making, weighing alternatives, working out social problems, and creating dialogue, all of which lead to a kind of exploratory learning.

Drama simply creates a great opportunity to make children read, and if they start to enjoy reading through drama, they may read more outside school. It provides students with background knowledge and general reading skills and, most importantly, with more positive attitudes toward learning (Smith \& Herring, 1993) and motivation for reading (King, 1981; McMaster, 1998). Since reading is a key to success in all stages of education, it must be fostered by effective methods and strategies. There is the need to gain a better understanding of how it can be used and improved as a method in reading classes and how it can help students develop positive attitudes toward reading. Research evidence shows that secondary school learners are deficient in reading skills and have also not cultivated the habits of reading widely (Unoh, 2000 and Lawal 2008). That is, there is the absence of the reading culture among the target learners. This is evident in the failure rates that are persuasive in the Junior School Certificate Examinations (JSCE) conducted yearly by internationally recognised examination bodies such as the West African Examinations Council (WAEC) and National Examinations Council (NECO). There is a general feeling that many Nigerian students do not like reading. Many teachers often complain about the poor reading habit among their students which can have implication on the personal and intellectual development.

Hence, the persistent failure of junior secondary students in English language has become a source of worry. This failure which is not so far from student's inability to recall and understand what has been read has further increased the pace of student's failure. English language has become focus of all eyes in the society and most especially in the educational institutions, to extent that a student is adjudge a good student based on his level of mastery of reading comprehension. But in spite of the great importance of English language, students still perform poorly in reading which is one of the major components of the English as a subject. This has become a source of worry to parents who waste money annually to enroll their wards in coaching centers in order to see their children pass English in external exams. Also, it has downplayed the efforts of teachers who spend extra time 
to give students the best. Different research works have been carried out to get to the root of students poor performance in the area of students inability to read and understand what has been read but not much success has been recorded. Hence the researcher sought to investigate the effect of drama technique on secondary school students reading achievement and attitude towards English language.

\section{Objectives of the Study}

The objective of the study is to examine the effect of drama technique on achievement in reading comprehension of junior secondary school students. The study also investigated the effect of gender as a moderating variable on achievement in English reading comprehension of junior secondary school students.

\section{Hypotheses}

1. There is no significant main effect of drama technique on achievement in English reading comprehension of junior secondary school students.

2. There is no significant effect of gender on achievement in English reading comprehension of junior secondary school students the

3. There is no significant interaction effect of drama technique and gender on achievement in English reading comprehension of junior secondary school students

\section{Methodology}

The study adopted the pre-test, post, control group quasi-experimental design. The various factors involved are the two treatments and control. The design will employ the $2 \times 2$ factorial matrix to enable the researcher consider the effects of the moderator variables alongside the effect of the treatment. The population of the study comprised of all junior secondary school students in ljebu-North Local Government, Ogun State. Two junior secondary schools were randomly selected for the purpose of the study. The study made use of two intact classes. The students in the two schools were randomly assigned to experimental and control groups. The study used Reading comprehension achievement test for data collection. The instrument was a twenty (20) items test. The instrument was validated given to experts in psychometrics to ascertain its content validity. The result obtained was used to establish 0.84 reliability coefficient using test-retest method. The data was analysed using ANCOVA at 0.05 level of significance.

\section{Drama technique Instructional Guide}

Week 1 Training of research assistant and administering Pre- test

Week 2 The teacher introduces the text.

Week 3 The teacher distributes characters to the students.

Week 4 The teacher monitors the students as they take on the character.

Week 5 The teacher supervises the rehearsal.

Week 6 The teacher watches the main acting and administer the Post Test on the students. 


\section{Control Group Instructional Guide}

Week1. Training of research assistant and administering Pre- test

Week 2. The teacher revises lesson of last class

Week 3. The teacher introduces the topic of the day

Week 4. The teacher asks the students to read comprehension passage

Week 5. The teacher summaries and concludes the class.

Week 6. The teacher revises and administers the Post Test on the students.

\section{Results}

Table 1: Descriptive statistics of respondents

\begin{tabular}{lll}
\hline Gender & Frequency & Percentage \\
\hline Male & 54 & 45 \\
Female & 66 & 55 \\
Total & $\mathbf{1 2 0}$ & $\mathbf{1 0 0}$ \\
Age & Frequency & Percentage \\
$10-12$ & 72 & 60 \\
$13-15$ & 48 & 40 \\
Total & 120 & 100 \\
\hline
\end{tabular}

Table 1, shows the frequency distribution of participants by gender. It shows that 54 (45\%) of the respondents are males while 66 (55\%) are females. This implies that majority of the participants of the study are females. The table also shows that 72 (60\%) of the respondents are within the age range of 10-12 while 48 (40\%) are within the age range of 13-15. This implies that majority of the participant of the study are within the age range of 10-12.

\section{Testing of Hypotheses}

Hypothesis 1: There is no significant main effect of drama technique on achievement in English reading comprehension.

Table 2: Summary of Analysis of Covariance of Achievement in English Reading Comprehension According to Strategy and Gender

\begin{tabular}{|l|l|l|l|l|l|}
\hline Source of Variation & Sum of Squares & Df & Mean Square & F & Sig. \\
\hline Main Effects & $990.246^{\mathrm{a}}$ & $\mathbf{1}$ & 495.123 & 6.887 & $\mathbf{. 0 0 1}$ \\
\hline Covariates (pre-test) & 220.099 & 1 & 220.099 & 3.061 & .000 \\
\hline
\end{tabular}




\begin{tabular}{|l|l|l|l|l|l|}
\hline Strategy (treatment) & 483.843 & 1 & 483.843 & 3.061 & $.083^{*}$ \\
\hline Gender & 464.614 & 1 & 464.614 & .6 .448 & .426 \\
\hline Interaction Effect & & & & & \\
\hline Treatment and gender & 6.548 & 2 & 3.274 & .616 & .028 \\
\hline Total & 441699.000 & 119 & & & \\
\hline Corrected Total & 9329.849 & 118 & & & \\
\hline
\end{tabular}

* indicate significant $F$ at .05 level $R$ Squared $=.104$

(Adjusted R Squared $=.089$ )

The result in Table 2 shows the outcome of the analysis to test the main effect of strategy (drama technique treatment) on achievement in English reading comprehension. The result in Table.2 shows significant outcome of the effect of treatments ( $F$ (118) $=.3 .061, \mathrm{P}<0.05)$, thus implying that the difference in the students' post-test mean achievement in English reading comprehension score after exposure to the treatment strategy and control group is statistically significant at the .05 level of significance. Hence, the null hypothesis one a $\left(\mathrm{H}_{0} 1\right)$ is rejected.

\section{Hypothesis 2: There is no significant effect of gender on achievement in English reading comprehension.}

The result of the main effect of gender in Table.2 further shows no significant main effect of gender on students achievement in English reading comprehension the $\left(F_{(1,118)} 6.448=P>0.05\right)$. This result implies that there is no significant difference between the post-test mean achievement in English reading comprehension score of the male and female students after exposure to the treatment strategies and conventional method used in the study. Hence, the null hypothesis $\left(\mathrm{H}_{0} 2\right)$ is retained.

Hypothesis Three: There is no significant interaction effect of drama technique and gender on achievement in English reading comprehension.

The result of the 2-way interaction effect of strategy and gender in Table.2 shows significant interaction effect of instructional strategy and gender on achievement in English reading comprehension $\left(F_{(2,118)}=.616, P<0.05\right)$. This outcome implies that the students' post-test mean drama score scores in reading comprehension across the levels of instructional strategies (Drama techniques and Conventional Method) used in the study vary significantly across the levels of students' gender (male and female). Hence, the null hypothesis $\left(\mathrm{H}_{0} 3\right)$ is rejected.

\section{Discussion and Conclusion}

Conclusively, this study concluded that there is significant main effect of drama technique on reading comprehension of participants. There is no significant main effect of gender on reading comprehension of participants. There is interaction effect of drama technique and gender on the reading comprehension of participants. There is significant main effect of drama technique on attitude towards reading comprehension of participant. There is no significant main effect of gender on attitude towards reading comprehension of participant. 


\section{Recommendations}

Based on the findings of this study, it is recommended that Curriculum planner should

create ways of incorporating drama technique of teaching in to the school curriculum. School administrators should see drama as alternative means of teaching reading. 


\section{References}

Aldavero, V. A. (2008) Drama in the development of oral spontaneous communication. Encuentro 17. Retrieved on 1/8/2010 from www. encuentrojournal. Org/textos/Alonso.pd

Booth, D. (1985). Imaginary gardens with real toads: Reading and drama in education. Theory into Practice, 24, 193-198.

Cunningham, A. E. \& Stanovich, K.E. (1997). Early reading acquisition and its relation to reading experience and ability 10 years later. Developmental Psychology, 33(6), 934-945.

De Certeau, M. (2008). Reading as Poaching. The Practice of Everyday Life. Trans. by S.F. Rendall. Berkeley: University of California Press.

DuPont, S. A. (1989). The effectiveness of drama as an instructional strategy to enhance the reading comprehension skills of fifthgrade remedial readers. Unpublished doctoral dissertation. The Pennsylvania State University.

Edomwandegbon, E. (June, 2005). An address delivered by the Honorable Commissioner for Education on the Occasion of the Institute of Continuing Education, Benin City first public lecture.

Ehrman, M., Leaver, B. \& Oxford, R. (2003). A brief overview of individual differences in second language learning. System, 31/3, $313-330$

Etim, F.E. (2007). Information literacy in an information age. In Etim, F.E. and Nssien, F.U. (eds.) Information Literacy for Library Search. Uyo: Abaam Publishing, pp. 72-89.

Ikota, N.R. (2004). Reading to write: A strategy for improving the writing performance of pre-service student teachers of English language. Literacy and Reading in Nigeria, 10(1), 105-112.

Jennings, J.H., Caldwell, J.S., \& Lerner, J.W. (2006). Reading Problems: Assessment and Teaching Strategies (5 ${ }^{\text {th }}$ ed). Boston: Allyn \& Bacon

Kariuki, PN and Humphrey, S. G (2010) The effect of drama on the performance of at-risk elementary math students. Intel. J. instruction. 1(2), 20-24.

King, N. (1981). From literature to drama to life. In N. McCaslin (Ed.), Children and drama (pp. 164-177). New York: Longman.

Lawal, R. A. (2008).Cultivating the Culture of Reading in Nigeria. A Paper delivered at the Fountain University, Osogbo, Osun State. February 4th, 2008.

Mabekoje, O. (2003). Understanding English. Ijebu- Ode, Nigeria: Tunigraphic Prints.

Maduabuchi, C.H. (2006). Relationship between reading ability and oral skills of EBSU students in language proficiency. Literacy and Reading in Nigeria, 11(1), 144-150.

McMaster, J. C. (1998). "Doing" literature: Using drama to built literacy. The Reading Teacher, 51(7), 574-84.

Mukherjee, A. (1979) Educational Psychology. Calcutta India: Basu Publishing Company.

Naiman, N., Fröhlich, M., Stern, H. H., \& Todesco, A. (1978). The Good Language Learner. Research in Education Series 7. Toronto, Canada: Ontario Institute for Studies in Education Press.

Obafemi, O. (March 19, 2006). Why reading culture is declining. Sunday Sun, 48. 
Oladunjoye, S.A.O. (2005). Systematic English for Schools, Colleges, and Universities. Lagos, Nigeria: SO4I Publishers.

Omojuwa, A. (1991). The teaching of reading in junior secondary school in Nigeria. Literacy and Reading in Nigeria, 1, 3-8.

Pritchard, S.C., Coltheart, M., Palethorpe, S., \& Castles, A. (2012). Nonword reading: Comparing dual-route cascaded and connectionist dual-process models with human data. Journal of Experimental Psychology: Human Perception and Performance, 38(5), 1268-1288.

Reese, L., Garnier, H., Gallimore, R. \& Goldenberg, C. (2000). A longitudinal analysis of the ecocultural antecedents of emergent Spanish literacy and subsequent English reading achievement of Spanish-speaking students. American Educational Research Journal, 37, 3: 633-662.

Rose, D., Parks, M., Androes, K., \& McMahon, S. (2000). Imagery based learning: Elementary students reading comprehension with drama tech niques. Journal of Educational Research, 94(1), 55-63.

Rubin, J. (1975). What the 'good language learner' can teach us. TESOL Quarterly, 9, 41-51.

Schneider, J. J., \& Jackson, S. A. W. (2000). Process drama: A special space and place for writing. The Reading Teacher, 54(1), 3851.

Smith, J. L., \& Herring, J. D. (1993). Using drama in the classroom. Reading Horizons, 33(5), 418-426.

Smith, J. L., \& Herring, J. D. (1993). Using drama in the classroom. Reading Horizons, 33(5), 418-426.

Smith, M. C. (1990). A longitudinal investigation of reading attitude development from childhood to adulthood. Journal of Educational Research, 83, 215-219.

Stern, H. H. (1975). What can we learn from the good language learner? Canadian Modern Language Review, 31, 304-318.

Tate, K. J. (2005). A conceptual lens for observing, analyzing, and interpreting data when exploring preservice drama. Youth Theatre Journal, 19, 151-167.

Tortello, R. (2004). Tableaux vivants in the literature classroom. The Reading Teacher, 58(2), 206-208.

Unoh, S.O (2000) Reading Problems in Secondary Schools. Journal of Language Arts (JLAC) Vol,1 No.1

Urian, D. (2000). Drama in education: From theory to "study cases." Contemporary Theatre Review, 10(2), 1-9. 